\title{
Students' Organizations in Canada and Cuba: A Comparative Study
}

\author{
Kendra Coulter (University of Toronto)
}

\begin{abstract}
As a comparative case study of two different national post-secondary students' federations, the Canadian Federation of Students (CFS), and the Cuban Federación Estudiantil Universitaria (FEU), this paper explores why postsecondary students organize politically. The history and present activities of each organization are reviewed to compare their work as it takes place in two very different national contexts. The paper then moves to a discussion of the political goals and motivations driving these organizations in the neoliberal present and argues that students in both organizations are engaged in similar efforts both to improve their own lives and social conditions more generally.

\section{Résumé}

Cet article, comme une étude de cas de deux fédérations nationales d'étudiants de deux pays différents, à savoir, la FCE canadienne (Fédération canadienne des étudiants) et la FEU cubaine (Federación Estudiantil Universitaria) examine pourquoi les étudiants universitaires s'organisent politiquement. L'auteure passe en revue l'histoire et les activités courantes de chacune des deux organisations pour comparer leurs œuvres qui ont été accomplies dans deux contextes nationaux très différents. L'auteure continue à discuter les buts politiques et les motivations qui commandent ces organisations dans le néolibéral présent. Elle soutient que les étudiants dans les deux organisations se sont engagés avec un effort semblable pour améliorer leurs propres vies et d'une façon générale, les conditions sociales.
\end{abstract}

\section{Introduction}

University and college students are unique and important social actors because they directly engage with post-secondary educational policies and institutions in their daily lives, and because, through their representative organizations, they demonstrate a collective interest in shaping both their immediate circumstances and wider social issues, both locally and globally. To explore how student organizations seek to make change in their home countries and in the wider, dynamic neoliberal world, this paper focuses on two different national postsecondary students' federations - the Canadian Federation of Students (CFS), and the Federación Estudiantil Universitaria (FEU) in Cuba. By focussing on the current work of two national students' national federations in two distinct countries, with different histories and relationships with the state and government, 
but also some notable commonalities, this study provides a comparative analysis of how and why students organize, particularly in the neoliberal present.

In this context, neoliberalism cannot be seen solely as an economic agenda, but rather must be understood as a multi-faceted project with real institutional and economic restructuring initiatives, coupled with reinforcing cultural, social and ideological processes, operating at a global and local level, and in varying ways (Gledhill, 2004; Peck \& Tickell, 2002). Gill (2000, p.3) defines it as an "economic, political and moral doctrine that posits the individual as the fundamental basis of society. More specifically, this ideology is rhetorically antistate and places unlimited faith in the 'magic of the market' to resolve all social problems." At the same time, neoliberalism must be seen as adaptive and resilient, but not monolithic or all-encompassing. However, there is an emphasis on competitive individualism, and on consumption as a source of identity. Consequently, a political cultural shift has occurred and continues to occur in many parts of the world. Public services are commodified and individualized, post-secondary education is constructed by neoliberal proponents in government and the corporate sector as an individual purchase to be paid for through user (i.e., tuition) fees. This is coupled with a project of material reorganization through which research funding is commercialised and privatised, and government investment in post-secondary education is constrained. This contextualisation is imperative for understanding the political terrain on which post-secondary students are currently living, organizing and resisting. How and why students organize in Canada and Cuba is interwoven with the dynamism and the inadequacies of neoliberalism.

With some notable exceptions, the political work of college and university student organizations has been relatively under-studied. However, student involvement in national and international anti-war and civil rights movements in the 1960s, particularly in the United States and France received considerable attention at the time (see, for example, Bakke, 1967; Altbach, 1967; Horn and Knott, 1971; Flacks, 1971; Harris, 1970) and there has been a resurgence of interest in the history of the 1960s in the last few years (Feenberg \& Freedman, 2001; Frey, 2004). Boren (2001) explores the history of student activism in the twentieth-century in an international context. In recent years scholars have probed student resistance to the actions of their national governments as well as protests against government inaction (e.g. Dugas 2001). In Canada, Axelrod (1989) has looked at the student movement in the 1930s, Roussopoulous (1970) was used. This reference reads 1971in the ref. list, which is a second edition of the same book] and Reid \& Reid (1969) explored student activism in the 1960s and Jasen (1989) and Owram (1996) studied Canadian students' political action in an historical perspective. Vickers (1976), McDonald \& Lenglet (1973), Adamson, Briskin \& McPhail (1988) and Sethna (2005) remind us of the activism of women students on campus. The role of Cuban postsecondary students, particularly in the Cuban Revolution of 1959 and thereafter, has also been explored (Cruz-Taura, 1989; Suchlicki, 1969; Wolf, 1969; Tovar, 1997). More recently, student protests in Chile, France, Quebec and Mexico, 
among others, have been documented (Woodard, 2000; Navarro, 2000; Labi, 2006; McSorley, 2005; Birchard, 2005), as has campus organizing against sweatshops (Featherstone, 2000). However, there is little scholarly work on contemporary student organizations per se and even less that is comparative in nature, a lacuna this paper begins to fill.

\section{Research Process}

This study draws heavily on primary sources available from the CFS and FEU. These include web sites, fact sheets, reports, submissions to government, press releases and promotional materials. These data were analyzed carefully to search for key concepts, messaging, slogans, campaign specifics, demands and goals for both organizations. I conducted two semi-structured interviews with elected CFS leaders in order to obtain their insights and analysis. I also participated in the CFS as Ontario Treasurer and President of the Graduate Students' Union at the University of Toronto which is Local 19 of the CFS. Thus I was involved with many of the campaigns and engaged with many of the student activists as a participant-observer. Although I was not able to arrange to interview students in leadership positions, I monitored the work of the FEU through the listserv of the Organización Continental Latinoamericana y Caribeña de Estudiantes (OCLAE, the Latin American and Caribbean Continental Students' Organization), an international students' alliance of more than two dozen progressive national and regional students' unions from across Latin America and the Caribbean, the main office of which is in Havana, Cuba. I also attended presentations by representatives of the FEU at II Encuentro Mundial de Amistad y Solidaridad (Second World Meeting of Friendship and Solidarity) in Havana in 2000 and the World Social Forum in Caracas, Venezuela in 2006.

\section{The Canadian Federation of Students - Strength in Numbers}

Canadian students have been politically active throughout the twentieth-century (Axelrod, 1989; Jasen, 1989; Owram, 1996; Hewitt, 2002; Levesque, 2005). In the 1960s, students organized into various anti-war and community development organizations as the Combined Universities Campaign for Nuclear Disarmament and the Student Union for Peace Action. By 1966 the Canadian Union of Students (CUS) had an explicitly political orientation and linked campus students' unions with broader coalitions fighting the nuclear threat, racism and Canadian complicity in the war in Vietnam. Harris (1970) and Owram (1996) both argue that by the mid-1960s, the student leaders in CUS were primarily interested in making connections between the university and larger, societal issues. In fact Owram (1996) states that by 1967, CUS had "transformed itself from a service organization into an activist body sympathetic to New Left ideas and programs," (p. 235). For a variety of reasons, in its last years, CUS had a volatile life and dissolved in 1970.

In 1981, the Canadian Federation of Students was formed to provide college and university students "with an effective and united voice, provincially and nationally" (CFS, 2006a). The CFS was founded on the principle that

64 Canadian and International Education Vol. 36 no.1 -June 2007 
education is a right and, with a view to achieving this goal, the Federation was intended to be the democratic, coordinating network and organizational framework for facilitating communication, administration and development among students and students' unions.

In 1995, a national student group called the Canadian Alliance of Students' Associations (CASA) emerged as a less critical and less progressive alternative to the CFS. At present, CASA has eighteen members while the CFS boasts more than eighty members representing college and university students, both undergraduate and graduate students. All member locals, that is, the individual students' unions that comprise the CFS, are represented in a provincial section and at the national level. The CFS structure contains provincial and national executives which are democratically elected, but the ultimate decision making bodies are the annual and semi-annual general meetings to which each member local sends delegates. Policies and campaigns are initiated at and subject to ratification at provincial and national general meetings.

Each member local has a representative on the provincial executive that meets regularly, and each province has an elected, full-time representative on the national executive, as well as a provincial chairperson. There are provincial and national offices, with elected leaders and paid staff members who undertake much of the coordination and material production stemming from decisions of the executives and general meetings, but local student unions actively campaign at the campus level through public forums, other educational campaigns, petition collection and demonstrations.

The CFS uses a three-pronged approach to meet its goals: research, government lobbying and membership mobilization. Current campaigns include work on freezing or reducing tuition fees, depending on the province; eliminating and reducing student debt; ending the deregulation of tuition fees and eliminating differential tuition fees for international students; fighting private, for-profit universities; and opposing transnational free trade agreements such as the Free Trade Area of the Americas (FTAA) and the General Agreement on Trade in Services (GATS), among others (see CFS 2006b, 2006c for a comprehensive list). The CFS also promotes anti-date rape, anti-racism and anti-homophobia educational campaigns. In addition, it coordinates cost-saving services and programs for students, provides a housing search-engine, and facilitates a student health insurance program.

To supplement direct government lobbying, the CFS coordinates national days of action to raise public awareness, garner media attention, further educate and engage students, and pressure current and future politicians. Such mobilizations also are used to foster and strengthen broader coalitions with other organizations, locally, provincially and nationally. For example, at the University of Western Ontario (UWO) in 2001, a large student protest called for a fullyfunded tuition fee freeze as part of the lead-up to the 2003 Ontario election. Thisaction was endorsed locally by the University of Western Ontario Faculty Association, the London Chapter of the Council of Canadians, the London and District Labour Council, among others, and involved college and high school 
students, as well. The CFS has developed many local, national and international coalition partners, including dozens of unions, anti-poverty organizations, and human rights organizations and, like the FEU, is a member of the International Union of Students.

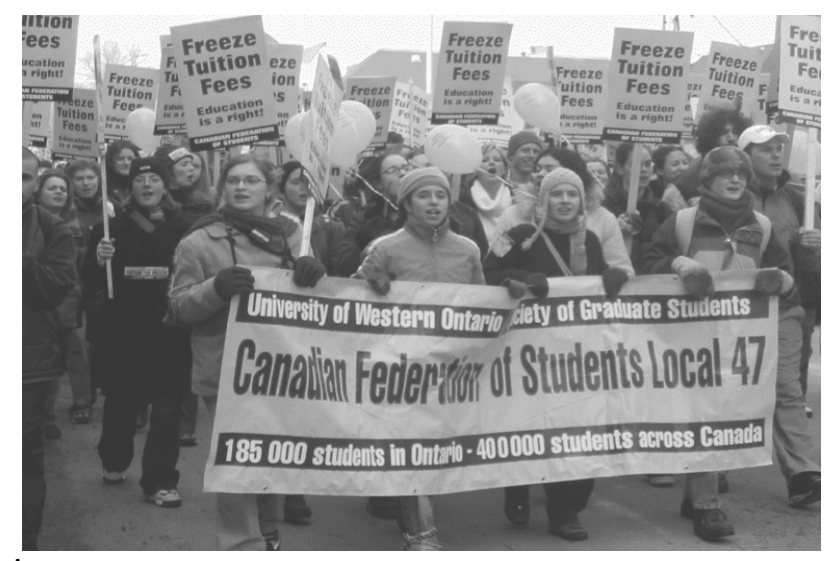

Figure 1. Students from the UWO protest for tuition freezes. Photo by Jordan Stone,

In the last few years, the CFS has had a particular focus on the many provincial and national elections that have occurred in and across Canada, deliberately seeking to shine a spotlight on the importance of post-secondary education issues for students, their families, and future students, all in an effort to make access to college and university a central topic of debate in elections. The CFS election campaigns have been driven by students' interest in resisting increasing government reliance on tuition and user fees to fund post-secondary education. Critical of downloading the costs of beneficial public services such as education onto individuals, the CFS opposes government reductions in public funding at national and provincial levels, and sees these reductions as part of a larger neoliberal agenda. Hence there is a desire on the part of the CFS to elect governments more conscious of the interests of students and more willing to promote a supportive social state.

The CFS also argues that neoliberal transnational trade agreements such as the FTAA will turn public services into sellable commodities and open the door for the possibility that corporations will challenge public funding for education in the courts as a form of "predatory pricing" and a "trade barrier" (CFS, 2001). Put simply, if the post-secondary education sector is turned into a "market," for-profit providers can use agreements such as the FTAA as grounds on which to sue governments for creating an unfair playing field by providing public funding to public institutions. The campaign against the FTAA includes member education, and member mobilization, and a substantial student presence and leadership role 
was visible at the anti-FTAA protests in Quebec City in 2001. The yellow placards and balloons of the CFS broadcast the message, in both French and English that "public education is not for sale." Students were insistent on emphasizing the threat to post-secondary education, but also to other public sectors such as health care, as well as to workers' rights and environmental protections in Canada and across the hemisphere. The explicit solidarity and unity with students from the Caribbean and Latin America who are also resisting the FTAA was incorporated into the CFS' anti-FTAA posters, stickers and other materials.

\section{Federación Estudiantil Universitaria: "The Cuban Revolution is the Achievement of Millions of Youth"}

Like Canadian students, students in Cuba also have been politically active throughout the twentieth century. The FEU was formed in 1922 (United Nations, 2006). In the 1950s, resistance to the Batista dictatorship was given primacy among the young and students were the first to protest his coup in 1952 (CruzTaura, 1989). As widespread discontent spread, the FEU began to organize revolutionary meetings, using university campuses as sanctuaries. Connections were formed among the FEU leadership and the armed rebel groups of Fidel Castro, Che Guevara, Celia Sanchez, Camilo Cienfuegos, Raul Castro, himself a student at the time, and others (Wolf 1969).

When the Cuban people successfully overthrew the military dictatorship of Batista in 1959, the FEU became a partner in the new Cuban state. This union is still celebrated by Duenas Oquendo, a student leader, who says that the "Cuban revolution is the achievement of millions of youth" (Hawkins and Stone, 2001, n.p.). In the early years of the revolution, Che Guevara (2000) spoke of the need to democratize and diversify the universities, a goal that is still being worked on to this day, especially within the FEU. Forty years after the victory, during a lecture at the University of Havana, Ricardo Alarcón, the President of the Cuban Parliament, celebrated the work of student leaders who break down the barriers between the intellectuals and the working class. At the same event, Armando Hart Davalos, former Cuban Minister of Culture, highlighted the fact that following the triumph of the Cuban revolution, the children of the workers, blacks and other ethnic minorities were able to attend post-secondary education institutions for the first time (Embajada de Cuba, January 11, 2002). Certainly access to education has been a central goal of the Cuban government and, as a result, some of the highest rates of literacy in the world can be found in Cuba. This is at least partly due to the fact that university students worked in the countryside, villages, towns and cities in a massive campaign to teach all Cubans to read and write (Elvy, 2004; Wald, 1978).

The FEU is now organized into the hierarchy of national Cuban political organizations as an association and a mass organization. Its role is to represent sectoral interests, explain state decisions, organize mass mobilizations and develop consensus among its members (Mastrapa, 2000). The FEU explicitly acknowledges that it promotes the Cuban Revolution and the work of the state 
among students, as well as representing the interests of students in the Cuban National Assembly and to the government overall (FEU, 2006). Elected student officials have voting rights in the National Assembly (Mericle, 1999) and many student leaders meet with Fidel Castro and other high ranking political officials to "debate... the main problems of this continent and the dramatic situation of most universities in the region where education serves the market and not life and liberty" (Embajada de Cuba, November 20, 2001). Student federations at all Cuban colleges and universities are members of the FEU and representatives are elected to local and national committees democratically (United Nations, 2006).

In Cuba, there are no tuition fees and students receive a monthly stipend from the government for basic living expenses. The FEU provides discounts to students for movie theatres, restaurants, local entertainment and cultural events (Bugansky, 2000). Free housing is provided for those students who attend postsecondary education institutions away from their family homes and many international students are educated in Cuba, particularly at the Latin American School of Medical Science, a world-renowned facility that trains students from underdeveloped nations, free of charge, to be doctors, after which they return to their home communities and countries.

As a political component of the Cuban state, the FEU plans, supports and promotes national political initiatives. It works in coalition with other Cuban organizations, especially the national workers' union (Confederación de Trabajadores Cubanos), the national women's organization (Federación de Mujeres Cubanas), the national association of small farmers (Asociación Nacional de Agricultores Pequeños) and the federation of middle school students (Federación Estudiantil de la Enseñanza Media) (Mastrapa, 2000). The FEU organizes conferences, seminars, political leadership training courses, and festivals such as the World Festival of Students and Youth that was held in 1997 to promote global solidarity with the struggles of students and working people (Cornejo, 1996). Further, the FEU has primary responsibility for organizing and supporting many national and international events for students, workers and political organizations, both proactively and in reaction to current events. These include student exchanges; international education campaigns about Cuba and the fight against imperialism; and solidarity and support work with radical, student and youth organizations from underdeveloped countries, particularly through the OCLAE (Hawkins and Stone, 2001; Mericle, 1999). The work of Cuban students is also evident in various international projects, the most notable of which is the ever-increasing presence of recent graduates from Cuban medical schools as they provide health care in poor neighbourhoods and regions of Latin America.

A major campaign of the FEU is opposition to the FTAA, although Cuba itself would not be part of the FTAA as it is excluded from the Organization of American States. The FEU, in collaboration with other representative organizations in Cuba, hosted a hemispheric anti-FTAA meeting in November of 2001 to oppose neoliberal domination of the Americas (Granma, September 6, 2001). It brought together representatives from non-governmental organizations, churches, unions and other social justice groups to share experiences and plan

68 Canadian and International Education Vol. 36 no.1 -June 2007 
alternatives. The FEU and other partners also hosted an international colloquium on promoting the social role of the university and international cooperation as an alternative to neoliberal globalization (OCLAE, 2002).

The FEU, with coalition partners from across Latin America, helps promote ALBA, the Bolivarian Alternative of the Americas, as it seeks to foster economic equality and multi-lateral cooperation in the region. ALBA rejects the neoliberal model of free trade, seeing it as another form of American imperialism. The need for Latin American countries to decide their own social and economic futures is emphasized (Salazaar, 2006). Overall, the main political work of the FEU is well summarized by a large banner that hung off the back of the Karl Marx Theatre in Havana during the II Encuentro Mundial de Amistad y Solidaridad in 2000. It read "globaliza la solidaridad" or globalize solidarity.

\section{Analysis and Conclusion}

Internally there are significant differences between the CFS and the FEU. The CFS, as a federation of student organizations, is constantly faced with the possibility of inner turmoil as the leadership and political orientation of their member locals on campuses change rapidly, often each year. At the provincial and national levels, there is a continuous negotiation of positions and policies. There are perpetual tensions around objectives and goals with some members arguing for an emphasis on student services while others support a more robust political engagement. The FEU, on the other hand, does not face the same dilemmas for while there can be political debate inside the organization and serious differences of opinion, in the Cuban state there is a shared commitment to the revolution and local university student organizations do not threaten to opt out of the national federation. It is clearly understood that the work of a student organization is political activism. And, because post-secondary education is free and universal in Cuba, the FEU does not have to devote any part of its resources to fighting for or protecting access to colleges and universities.

However, despite different histories, economies, and relations with their respective governments, both the CFS and the FEU share an interest in values like equality and solidarity, as well as a fundamental belief in the importance of education for individual students and for society at large. Both organizations see education as part of a broader progressive political agenda. Consequently, both take proactive steps to shape policy related to their sector, while also promoting social justice more generally, but they do so in different ways because of the specificities of their political locations within their respective states.

Put another way, student organizations are shaped by the ideological and institutional terrain on which they exist. With an official position within the Cuban state, the FEU has many opportunities to shape policy directly and to act on behalf of its sector. It has, as it were, a place at the table. At the same time, because of this incorporation into the state apparatus, it becomes more difficult to adopt an oppositional stance should disagreements arise, and once decisions are made the FEU is expected to carry them to students. On the other hand, the CFS is not a formal part of the Canadian state, and hence must work to shape policy 
mainly through lobbying meetings, street protests, petitions and the like. This allows for considerable independence but also makes it possible for governments to shut out students' voices from the debate. The CFS becomes simply one interest group among many trying to shape education policy.

Formally and informally, social and political education is interwoven with the reality of contemporary Cuban culture. Cuban students defend Cuba's sovereignty and develop their own sophisticated analysis of the complexities of political life in their country, a nation which maintains its socialist organization despite substantial attempts from outside forces, especially the United States government, through the more than forty year old economic blockade of the island, to re-introduce capitalism. Cuban students do not have to worry that their post-secondary institutions are threatened by national or foreign private investors; nonetheless, they have not opted to accept their universal education system, of which they are very proud, as an excuse to refrain from political organizing. Instead, the FEU works in collaboration with representative organizations in Cuba and abroad to combat the negative impacts of neoliberalism and to support other students who do not have free post-secondary education. Currently, with the election of Hugo Chavez in Venezuela and Evo Morales in Bolivia, particularly close ties have developed with those countries and Cuban students are active in helping to build alternatives to neoliberalism.

In Canada, the situation is more complex. Governments actively support user fees for post-secondary education, promote public-private partnerships for educational funding and encourage the commercialization of research. While Canadians continue to support public education overall, the country's political culture is complicated by a merging of progressive and neoliberal ideas, sentiments and policies. Consequently, the CFS has been required to focus most of its efforts on organizing with and for students on specific education issues. However, the CFS recognizes that rising tuition fees and the de-prioritisation of public services are related to the wider deregulation and privatization agenda of neoliberalism and thus seeks to resist this trend at all levels of government.

The CFS strategically adapts its campaigns to take account of the dynamism of political culture, the condition of the provincial or national economy, the party in power at the federal or provincial levels, and other factors. In some years and places Canadian students lobby and organize for a tuition fee reduction, in others a tuition fee freeze. However, the organization is still driven by its primary principle, that education is a right. Although short-term strategies differ, a fully-funded, universally accessible, high quality post-secondary education system remains the ultimate objective. Seeking genuine access to education, without financial barriers is seen as part of promoting a transformative political agenda, and challenges the ideas and policies of neoliberalism. In addition, by outlining how the FTAA would threaten public services like education by reorganizing the education sector into an expensive, for-profit industry, the CFS is making its anti-neoliberal agenda explicit. It is criticizing contemporary conditions and promoting alternatives by challenging the individualization and corporatization of education.

70 Canadian and International Education Vol. 36 no.1 -June 2007 
The CFS and the FEU both recognize the importance of students organizing around their own particularities and both promote education that is universally accessible and affordable. The CFS and FEU are part of a broadbased, social and cultural movement that challenges the ideas and institutions of neoliberalism, and promotes collectivity, redistribution and equality. The defence of education is about students and the inherent value of a quality education, but it is also about the benefits for society at large and the world. The answer to why students organize is, on the face of it, historically and culturally variant, yet it is also fundamentally intertwined with a commitment to progressive social change. Students who work together for social change have identified ideas and institutions, policies and politicians that are detrimental to themselves and their communities. They have taken the neoliberal assault personally but they have also examined the broader political terrain, nationally and internationally, and made common cause with other social movements, thus demonstrating not only their understanding of the interconnections among the economic, political and social, but also their altruism. Both the FEU and the CFS understand that education is part of the process through which students develop their consciousness and critique the world. In this regard, they believe that postsecondary education is a universal public service and it must serve the public, as well.

\section{References}

Adamson, N., Briskin, L., \& McPhail, M. (1988). Feminist organizing for change: The contemporary women's movement in Canada. Toronto: Oxford University Press.

Altbach, P.G. (1967). Students and politics. In. M.S. Lipset (Ed.), Student politics (pp. 7493). New York: Basic Books, Inc.

Axelrod, P. (1989). The student movement of the 1930s. In P. Axelrod and J. G. Reid (Eds.), Youth, university and Canadian society: Essays in the social history of higher education (pp. 216-246). Kingston, Montreal \& London: McGillQueen's University Press.

Bakke, E.W. (1967). The roots and soil of student activism. In. M.S. Lipset (Ed.), Student Politics (pp. 54-73). New York: Basic Books, Inc.

Birchard, K. (2005). Québec strike ends, but tensions linger. The Chronicle of Higher Education, 51, p. A45

Boren, M. E. (2001). Student resistance: A history of the unruly subject. NewYork \& London: Routledge.

Bugansky, T. (2000, November 3). Cuba: Different System, Similar Students. Retrieved on October 20, 2001 from www.stater.kent.edu/stories_old/00fall111400UniversityofHavanaTB.html. 
Canadian Federation of Students. (2001). How the FTAA threatens post-secondary education.

Canadian Federation of Students. (2006a). Retrieved August 2, 2006 from http://www.cfs-fcee.ca/html/english/about/index.php. .

Canadian Federation of Students. (2006b) Retrieved August 2, 2006 from: http://www.cfs-fcee.ca/html/english/research/fact_sheets.php. .

Canadian Federation of Students. (2006c). Retrieved August 2, 2006 from: http://www.cfs-fcee.ca/html/english/campaigns/background.php. .

Cornejo, C. (1996). Young Activists Meet in El Salvador to Discuss Struggle Against Imperialism. The Militant, 60. Retrieved November 26, 2001 from www. hartford-hwp.com/archives/40/070.html.

Cruz-Taura, G. (1989). Cuba. In P.G. Altbach (Ed.) Student political activism: an international reference handbook (pp. 371-382). New York: Greenwood Press.

Dugas, J. C. (2001). The origin, impact and demise of the Colombian student movement: Insights from social movement theory. Journal of Latin American Studies, 33, pp. $807-838$.

Elvy, J.C. (2004). Notes from a Cuban diary: Forty women on forty years. Journal of Transformative Education, 2, 173-186.

Embajada de Cuba en Canada (2001, November 20). Cuba News. Message posted to undisclosed recipients.

Embajada de Cuba en Canada. (2002, January 11). Cuba News. Message posted to undisclosed recipients.

Featherstone, L. (2000). The student movement comes of age. The Nation, May 15, 271, pp. 23-28.

Feenberg, A., \& Freedman, J. (2001). When poetry ruled the street: The French May events of 1968. Albany, NY: SUNY Press.

Federación Estudiantil Universitaria (2006). ¿Quienes somos? Retrieved August 6, 2006 from http://www.joven.cu/Organizaciones/H-FEU/feuquienesomos.htm.

Flacks, R. (1971). The liberated generation: An exploration of the roots of student protest. In P.D. Knott (Ed.), Student Activism (pp.74-97). Dubuque, IA: Wm. C. Brown Company Publishers.

Frey, M. (2004). Shifting to confrontation: Herbert Marcuse and the transformation of the American student movement. GHI Bulletin, 34, 99-111.

Gill, L. (2000). Teetering on the rim: Global restructuring, daily life and the armed retreat of the Bolivian state. New York: Columbia University Press.

Gledhill, J. (2004) Neoliberalism. In D. Nugent and J. Vincent (Eds.), The companion to the anthropology of politics (pp.332-348). Malden, Oxford \& Carlton: Blackwell Publishing.

Granma Internacional (2001, September 6). FTAA: Devouring the Region's Economies. Retrieved November 26, 2001 from www.granma.cu/ingles/septiem1/36alca-i.html .

Guevara, E. (2000). Che Guevara Talks to Young People. D. Deutschmann (Ed.). New York: Pathfinder Press.

Harris, J. (1970). Students in revolt. New York: McGraw-Hill Book Company. 
Hawkins, A \& Stone,B. (2001). Cuban revolution is the achievement of millions. The Militant, 65. Retrieved August 20, 2006 from www.themilitant.com/2001/6514/index.shtml .

Hewitt, S. (2002). Spying 101: The RCMP's secret activities at Canadian universities, 1917-1997. Toronto: University of Toronto Press.

Horn, J.L. \& Knott, P.D. (1971). Student activists and student activism. In P.D.Knott (Ed.), Student Activism. Dubuque, IA: Wm. C. Brown Company Publishers.

Jasen, P. (1989). "In pursuit of human values (or laugh when you say that)": The student critique of the arts curriculum in the 1960s. In P. Axelrod and J. G. Reid (Eds.), Youth, university and Canadian society: Essays in the social history of higher education (pp. 247-271). Kingston, Montreal \& London: McGill- Queen's University Press.

Labi, A. (2006). France roiled by student demonstrations. The Chronicle of Higher Education, 52, p. A52.

Lévesque, A. (2005). Student life at McGill. In A. Lévesque (Ed.), Madeleine Parent: Activist (pp. 37-58). Toronto: Sumach.

McDonald, L., \& Lenglet, M. S. (1973). The status of women at McMaster University. In M. Stephenson (Ed.), Women in Canada (227-244). Toronto: New Press.

Mastrapa, A.F. (2000). Government and Politics of Cuba. Retrieved November 26, 2001. www.cubapolidata.com/gpc/gpc institutional_order.html

McSorley, T. (2005). Strike was successful but fresh battle looms. Canadian Dimension, 39, pp. 13-14.

Mericle, D. (1999, August 26). SECA-Led Delegation Returns from Trip to Camaguey. Retrieved on October 10, 2001 from www.seca.org $/ \mathrm{html} / \mathrm{press}$ release_on_august 26 19.html. .

Navarro, L.H. (2000). The UNAM stalemate: Mexico's student strike. NACLA Report on the Americas, 33, pp.19-23.

OCLAE (2002). Que es la OCLAE? Retrieved August 2, 2006 from: http://www.feuu.edu.uy/documentos/otros/oclae/oclae.html.

Owram, D. (1996). Born at the right time: A history of the baby boom generation. Toronto: University of Toronto Press.

Peck, J \& Tickell, A. (2002) Neoliberalizing Space. Antipode, 34, 380-404.

Reid, T., \& Reid, J. (Eds.). (1969). Student power and the Canadian campus. Toronto: Peter Martin.

Roussopoulous, D. (1971). The new left in Canada. Montreal: Our Generation Press.

Salazar, L. S. (2006). Cuba's foreign policy and the promise of ALBA. NACLA Report on the Americas, 39, pp. 27-44.

Sethna, C. (2005). The University of Toronto Health Service, oral contraception, and student demand for birth control, 1960-1970. Historical Studies in Education, $17,265-292$.

Suchlicki, J. (1969). University students and revolution in Cuba, 1920-1968. Coral Gables FL: University of Miami Press.

Tovar, C.M. (1997). Democracy in Cuba? Havana: Editorial Jose Marti.

United Nations (2006). Cuba: National Youth and Student Coordinating Bodies. Retrieved on August 2, 2006, from www.visionoffice.com/unyin/country5.asp?/countrycode $=\mathrm{cu}$

Vickers, J. (1976). Women in the universities. In G. Matheson (ed.), Women in the Canadian mosaic (pp. 199-240). Toronto: Peter Martin. 
Wald, K. (1978). Children of Che: Childcare and Education in Cuba. Palo Alto, CA: Ramparts Press.

Wolf, E.R. (1969). Peasant wars of the twentieth century. Norman OK: University of Oklahoma Press.

Woodard, C. (2000). Worldwide tuition increases send students into the streets. The Chronicle of Higher Education, May 15, pp. A54-A56.

Kendra Coulter is a PhD candidate in the Department of Anthropology at the University of Toronto. Her research interests include the politics of neoliberalism, gender, class, public policy and resistance. She can be reached at: kendra.coulter@utoronto.ca. 